\title{
Somos todos brasileiros? Estudo sociológico sobre a moderna divisão do trabalho social brasileira: trajetórias ocupacionais de trabalhadores brasil- ienses da construção civil - 1992/2003
}

Marcelo Alvares de Sousa

Curso: Doutorado em Sociologia

Data da defesa: 26 de abril de 2006

Orientadora: Prof ${ }^{\mathrm{a}} \mathrm{D}^{\mathrm{a}}$ Christiane Girard Ferreira Nunes

\section{Resumo}

O tema da pesquisa é o moderno vínculo social brasileiro e suas tendências contemporâneas de evolução, do ponto de vista da divisão do trabalho social. O estudo da integração social e sistêmica em sociedades individualistas modernas possibilitou ressaltar especificidades da constituição da moderna sociedade brasileira. As sociedades européias tenderam a estruturar-se com base no individualismo moral, na divisão do trabalho social e em sistemas de cidadania social. Por sua vez, a modernidade brasileira caracterizouse pelas instituições da cordialidade, subdesenvolvimento e cidadania regulada. Brasília simbolizou seu projeto de modernidade.

A perda contemporânea de centralidade do trabalho implicou para as sociedades modernas européias a ruptura do pleno emprego como padrão de divisão do trabalho social. Esse processo acentuou os limites da ideologia individualista e dos sistemas de cidadania 
social para garantir o vínculo social europeu contemporâneo. A existência de supranumerários sugere uma evolução do trabalho europeu em direção a uma estrutura análoga ao subdesenvolvimento do trabalho brasileiro.

Para a sociedade brasileira, a reestruturação contemporânea do trabalho implicou a renovação de sua estrutura hierárquica moderna. A análise da trajetória ocupacional de trabalhadores brasilienses da construção civil entre 1992-2003, por meio do indicador de capital ocupacional, identificou a precarização generalizada das ocupações não-regulamentadas como uma das características da reestruturação contemporânea do trabalho no Brasil. A manutenção e aprofundamento da estrutura de subdesenvolvimento e segmentação de sua divisão do trabalho ensejam indagações sobre as tendências da autoprodução contínua da sociedade brasileira contemporânea, em particular no que tange aos limites da ideologia da cordialidade e de sua estrutura de subdesenvolvimento e segmentação sistêmica.

Palavras-chave: Brasil, cidadania, trabalho, trajetórias ocupacionais, capital ocupacional, Brasília, construção civil, Émile Durkheim.

\section{Programa de Atendimento ao Superdotado da Secretaria de Estado de Educação do Distrito Federal (1991-2002): inclusão social ou tergiversação burocrática?}

Marília Gonzaga Martins Souto de Magalhães

Curso: Doutorado em Sociologia

Data da defesa: 4 de agosto de 2006

Orientador: Prof. Dr. Lúcio de Brito Castelo Branco 